\title{
Preface to the 2009 Edition
}

Evolution's Rainbow surveyed the extensive diversity in sex, gender, and sexuality now known to exist among both nonhuman animals and people. When the book appeared in 2004, the extent of same-sex sexuality in animal societies was poorly publicized, even among biologists. Other phenomena such as gender multiplicity, sex-role reversal, and sex changes were even less well known. Biology undergraduates as well as the general public were being misled by textbooks and nature shows into thinking of a heterosexual binary as "nature's way." Today the situation has begun to improve; for example, exhibitions for the general public about gender and sexuality diversity opened in 2006 at the Natural History Museum of the University of Oslo, Norway, and in 2008 at the Museum of Sex, in New York City. Also in 2008, the Lesbian and Gay Veterinary Medical Association produced a DVD of my lecture at its 2007 annual conference in Washington, DC, titled Sexual Diversity in the Animal Kingdom, distributed through Amazon.com. Although it may be decades before information about the extent of sexual and gender diversity becomes common knowledge, the genie is out of the bottle at last.

The challenge today is to work through the implications of this diversity whose reality destabilizes our understanding of biological nature. The standard evolution ary account of gender and sexuality originates with Charles Darwin's writing on the topic of "sexual selection" and 
these specific writings-not his overall theory of evolution-are challenged by the new information. I concluded in 2004 that the extent of this diversity pointed to sexual selection's being on the wrong track. I proposed that Darwin's theory of sexual selection should be replaced by a new theory that I christened "social selection." Whereas sexual selection emphasizes mating, focusing on who mates with whom, social selection would emphasize participating in a social infrastructure to produce and raise offspring, and would focus more on how to deliver offspring into the next generation than on how to attract mates. In the social selection context, the diversity of gender and sexuality makes evolutionary sense, rather than seeming at odds with evolution, because of the valuable social roles the diversity represents.

In 2004, and probably even today, most biologists believe that Darwin's original sexual selection theory can somehow be widened and extended to account for gender and sexuality diversity. I don't think so. To the contrary, since 2004 the evidence and theoretical arguments against sexual selection have grown so much that those who continue to champion sexual selection theory are, I think, uninformed or in denial. Meanwhile, work on developing social selection into an alternative to sexual selection continues in my laboratory. This reissue of Evolution's Rainbow accompanies the publication in 2009 of my new book, The Genial Gene, which extends my critique of sexual selection based on studies that appeared after 2004 and provides a summary of the research from my laboratory on social selection.

In addition to discussing diversity in gender and sexuality among animals, Evolution's Rainbow, in the third of its three parts, reviewed gender and sexuality across cultures and through history. In particular, I called attention to passages in the Bible, in both the Christian and Hebrew Testaments, that teach the inclusion of gender-variant persons in community and worship. This theme has been taken up by religious scholars at Loyola University, Chicago, resulting in a book, Christianity, Gender, and Human Sexuality: An Interdisciplinary Dialogue, by Marie Vigen and Patricia Beattie Jung, to be published in 2009. Also since 2004, many advances have taken place in the public sector to secure rights for diverse people, although much remains to be done. Only in medicine and psychology, the areas treated in the middle part of the book, has the 
progress been disappointing since 2004. These professions are still dominated by binarist thinking that retards coming to grips with the facts of diversity.

I hope you enjoy this reissue of Evolution's Rainbow. The book was exciting, even exhilarating, to write as I was uncovering fascinating information that I knew would be inherently interesting to many and would also challenge our preconceptions about what is biologically natural.

San Francisco

August 2008 
This page intentionally left blank 